\title{
Confirming University Students' Individual Reading Habit on Academic Text
}

\author{
Herman Resyadi*1, Dea Serly Safitri ${ }^{2}$, \& Darmawati Fitriansyah ${ }^{3}$ \\ ${ }^{1}$ Department of English Education, Institut Agama Islam Negeri Bone, Indonesia \\ ${ }^{2,3}$ Universitas Negeri Makassar, Indonesia \\ * Corresponding Author Email: hermanresyadi24@gmail.com
}

\begin{abstract}
The main concern of this research was aimed at confirming the students' individual reading habit on academic text. It was navigated by online descriptive survey which involved 31 students of English Education program. The data were collected through online questionnaire on WhatsApp Group Discussion by considering under the Covid19 situation and analyzed by using SPSS. The result exposed (1) that the students have positive feeling on academic text, (2) most of the students read academic text at least once a week, (3) Academic book is the most types of academic text read by the students, (4) Busy with assignments becomes the main reason why the students not reading academic text. This research confirmed that the students have sufficient reading habit on academic text.
\end{abstract}

Keywords: Academic Text, Reading, Habit, University Students

\section{INTRODUCTION}

One of essential way to achieve the maximum knowledge is by reading. Chettri and Rout (2013) argue that success and failure of students' academic life depends on their reading ability. Syahputra (2016) also believes that reading is the best receptive skill in learning language to get the knowledge. Therefore, a successful reading determines educational accomplishments, it also supports to develop the knowledge and language skills. Taking this on board, it can be assumed that reading is a receptive activity which has impact on students' academic life.

As reading is a receptive activity, it becomes as a habit when it repeated consistently. This means that reading habits is depending on the frequency, materials and amount of time spent to read (Rosli et al., 2017). Shen (2006) also recognizes reading habit as how frequent and how much the students do reading which becomes important for the students especially in a circumstances where required reading as a main activity (e.g. school, university, work). Palani (2012) argues that reading habit is an essential aspect of shaping personality which assist to enhance proper thoughts and producing fresh ideas. Simply, reading habit can be defined as a consistent activity engaging with text for personal advance or pleasure.

Many researchers, scholars and linguist adhere to view that reading habit as a vital aspect on reading activity. Currently Maharsi et al. (2019) tried to identify the students' reading habit and perception on reading for pleasure. Their research revealed that students have low reading interest on the reading culture which has not been adequately improved on their early ages. Additionally, Skenderi and Ejupi (2017) exposed that the students have low reading habit and the reasons weaken their habits are by the social media, school activity, and the lack of intention in reading. Moreover, Kurniasih (2017) argues that the government has authority to provide good quality of reading materials and sources based on the interest, needs, and behavior. In this part, the researcher assumes that reading habit is a crucial entity 
IJRETAL

International Journal of Research on English Teaching and Applied Linguistics, Vol. 1, No.1, June 2020

not only for students themselves but also for the government since it should be established on early ages of students' academic life.

In university context, reading activity is required to sustain the students' learning process during study. Considering the lesson from the lectures is not sufficient to make the students' getting better. Thus, reading is necessary for the knowledge improvement as well as to enhance students' quality of life. In fact, based on the preliminary research many students do not familiar or even rarely engaging with the reading text during their study.

To provide contextual objectives, the researcher focused to confirm the students' individual reading habit on academic text and provide some possible recommendation on the impact of reading habit. The central theme of inquiry reviews and discusses briefly the students' reading habit on academic text followed by presentation of data. It then exposed the reasons on engaging the academic text during study in university. Here, the researcher argues that reading habit on academic text has substantial influence on academic life of the students. It may contributes towards a better understanding and the development of curriculum and lesson plan by the stake holders in charge.

\section{RESEARCH METHOD}

For the comprehensive of investigation, this research adopted the online descriptive survey by considering under the condition of Pandemic Covid19 and its practical usage according to the standard criteria. The research involved 31 samples of English Education students at $4^{\text {th }}$ semester. The researcher distributed online questionnaire via WhatsApp Group discussion and analyzed using SPSS. The advantage of this method is more effective and efficient to collect the data in the Pandemic Covid19 situation and gathering convincing statistical data. On the other hand, this method was less of exploring controversial issues.

\section{RESULT AND DISCUSSION}

The following tables show the questionnaire response in frequency and percentages.

Table 1 . Do you enjoy reading academic text?

\begin{tabular}{|c|c|}
\hline Do you enjoy reading academic text? & Percentage \\
\hline YES & $58.1 \%$ \\
\hline $\mathrm{NO}$ & $41.9 \%$ \\
\hline
\end{tabular}

The table 1 can be expressed more simply as the response of question whether or not the students enjoy reading academic text. The result of this survey indicated that students were dominated enjoying the reading academic text by the percentage of $58.1 \%$ of affirmative and the rest $41.9 \%$ of the students of contrary.

The result that emerges from table 1 is clear that the students have positive feelings on the academic text where it is an imperative response on enjoying the academic text. This point is particularly relevant to Maharsi et al. (2019) which found that students have positive reading habits on the particular types of text. Additionally, similar findings has been reported by Iftanti (2012) which confirms that most students have positive claim on their own reading habit. This positive emotion on the reading academic text brings positive impact during students' study, it can also embrace them to have helpful attitude toward academic text (Erlina et al., 2019). From this perspective, a good reading habit will lead to the constructive learning comprehension on the classroom material. One possible explanation is without positive reading habit the students will have difficulties on the process of learning, especially the language learning where reading is a super supplement material to improve some language elements (vocabulary, pronunciation, etc.) and the other language skills. 
IJRETAL

International Journal of Research on English Teaching and Applied Linguistics, Vol. 1, No.1, June 2020

Even though most students express positive feeling on enjoying academic text. Another important point is $41.9 \%$ students argue that they do not enjoy reading academic text. This negative feelings on academic text is potentially weaken students personal belief regarding the advantages of reading academic text (Aukerman \& Schuldt, 2015). At issue here is many students do not enjoy reading academic text which means they are not interested and have low self-beliefs on the academic text and its importance in study at university. Arguably, the students who have positive feeling on academic text will have influence on their reading ability and who have the negative feeling will have low reading beliefs and ability.

Table 2. How often do you read academic text?

\begin{tabular}{|l|l|}
\hline \multicolumn{1}{|c|}{ How often do you read academic text? } & \multicolumn{2}{c|}{ Percentage } \\
\hline Once a week & $54.8 \%$ \\
\hline Once a month & $35.5 \%$ \\
\hline Once a year & $7.6 \%$ \\
\hline Never & $2.1 \%$ \\
\hline
\end{tabular}

In the previous discussion, habit is considered as consistent reading activity depending on the frequency, materials and time spend. As seen in the table 2 the statistic clearly shows that the students were mostly read academic text at least once in a week $(54.8 \%)$ and a small number of students who never engaging with academic text $(2.1 \%)$. Shortly, table 2 it confirms that there are more students who have high frequency on reading the academic text than the students who never read academic text at all.

A support for this statistical data interpretation comes from Iftanti (2012) which also found that the students only spend to read one book in a week. In one side the $54.8 \%$ students read academic text once a week, from this standpoint the data exposed that the students have awareness of educating themselves by reading the academic text in sufficient frequency. In the other side, the rest of students who rarely and never read academic text is considered in a disadvantage area, since for university students reading academic text is a must. As explored by Anyaegbu et al. (2016) lack of the reading habit will result to an inability of effective learning and equally influence their academic performance. In the same study, Annamalai and Muniandy (2013) also discovered that low reading attitude and habits cause the increasing reading anxiety to a particular text. A valid point is that the students who rarely and never read any of academic text during their study will consequence on a difficulties during learning process and process of finishing study.

Table 3. When did the last time you read academic text?

\begin{tabular}{|l|l|}
\hline \multicolumn{1}{|c|}{ When did the last time you read academic text? } & \multicolumn{1}{c|}{ Percentage } \\
\hline Last week & $64.5 \%$ \\
\hline Last month & $16.1 \%$ \\
\hline Within the last three months & $19.4 \%$ \\
\hline Never & $0 \%$ \\
\hline
\end{tabular}

The statistical data on the table 3 presents that all the students have engaged with academic text. The table 3 also shows that students lastly engaging with academic text last week (64.5\%) and the least was within last three months (19.4\%). This proves that students were currently engaging with academic text which clarifies the study from Iftanti (2012). Even though all the students are already engaging with academic text however the distribution of its habit is still show a number low tendency of reading academic text. It is based on the 
IJRETAL

International Journal of Research on English Teaching and Applied Linguistics, Vol. 1, No.1, June 2020

students who read within last three months $(19.4 \%)$ of the data which showed there are still students who have very low interest on reading the academic text.

A research which has been examined extensively by Acheaw-Owusu (2014) exposed that low reading habits will influence students' academic performance. This reason is supported by Cimmiyotti (2013) on the study which found the more the students read the more gained information and awareness. Hence, this frequency of reading habit is really significant to sustain the academic performance in university as well as to expand information and awareness. The data on table 3 indicated that many students still have low reading habit on the last academic text they have read, once in a month and within last three months. As mentioned in the previous discussion that reading habit can influence academic performance. By this result, a point can be made is students who has low reading habit will hypothetically have more difficulties in their academic life.

Table 4. Types of academic text mostly read by students

\begin{tabular}{|l|l|}
\hline \multicolumn{1}{|c|}{$\begin{array}{c}\text { Types of academic text mostly read by the } \\
\text { students }\end{array}$} & \multicolumn{1}{c|}{ Percentage } \\
\hline Academic Book & $56.7 \%$ \\
\hline Journal & $23.3 \%$ \\
\hline Essay & $16.7 \%$ \\
\hline Research paper & $3.3 \%$ \\
\hline Thesis & $0 \%$ \\
\hline Conference paper & $0 \%$ \\
\hline
\end{tabular}

A particular attention paid to the table 4 which verifies most students engaging with academic book (56.7\%), then followed by journal (23.3\%) and essay (16.7\%). The table 4 also showed that students were having less reading habit on research paper (3.3\%), Thesis $(0 \%)$ and Conference paper $(0 \%)$. The table 4 indicates that most students have high interest on academic book and low interest in research paper, and never engaging with thesis or conference paper.

A noteworthy study found by Erlina et al. (2019) who clarify that the reading habit on particular text has close significant correlation on the academic achievement. Based on the table 4 data, this low reading habit on the research paper, thesis, and conference paper will consequence on the low current knowledge and development on the trending information. From this perspective, when the students can manage their reading habit this will automatically improve their academic achievement. Academic book is worthy to read however the research paper, thesis, and conference paper are also valuable. In view of this, when the students have low reading habit on academic text it may weaken their comprehension and ability to get information, fact, and data from the text. Not only about comprehension, this low reading habit on academic text is potentially weaken ability to make argument and exposure to different perspectives.

Table 5. Reason for not reading academic text

\begin{tabular}{|l|l|}
\hline \multicolumn{1}{|c|}{ Reasons for not reading the academic text } & \multicolumn{1}{c|}{ Percentage } \\
\hline Busy with assignments & $35.5 \%$ \\
\hline Academic text is boring & $29 \%$ \\
\hline I do not understand academic text & $19.4 \%$ \\
\hline Spending time on social media & $7.25 \%$ \\
\hline Do not have right condition & $4.42 \%$ \\
\hline Do not understand the meaning of context & $4.42 \%$ \\
\hline
\end{tabular}


IJRETAL

International Journal of Research on English Teaching and Applied Linguistics, Vol. 1, No.1, June 2020

The table 5 reports that there are several reasons why the students are not reading academic text. The analysis of the data revealed that students were busy with assignments $(35 \%)$. It is more likely that assignments is a time consuming activity which make the students do not have enough time to do reading time. This findings is similar with Skenderi and Ejupi (2017) which exposed that students' school assignments becomes another single factor of not reading the academic text. Arguably, most students not reading academic text because lean more on doing assignment rather than reading academic text.

The second, students confess that academic text is boring (29\%). An important point to bear in mind that when the students deem the academic text is boring this will slow up their knowledge enhancement. On this reason the lecture has the responsibility to make the academic text pleasurable for the students by using interesting teaching method which is connected with the academic text context. This might build the students' interest on academic text during their learning process.

The third, students stated that they do not understand with academic text (19.4\%). This point is particularly relevant to unfamiliarity background of academic text, this strongly means the students do not understand the academic text because they do not familiar with it. Undoubtedly case exposed that lacking interaction with academic text since early years in the university will ensue on the under capacity of understanding the academic text and their academic achievement (Erlina et al., 2019). This reason is related on the other reason that the students do not understand the context of academic text $(4.42 \%)$ which is the result of unfamiliarity leads to the incapability of understanding the context of academic text. The last was students are not reading academic text because spending time on social media $(7.25 \%)$ and do not have the right condition (4.42\%). Up to this point, as Skenderi and Ejupi (2017) previously shown, not only assignment makes the students not reading but also the social media and the unconditional time becomes the factor of low reading habit. A strong point that can be made is that the students still have low time management skill which consequences on the low reading habit especially the academic text.

\section{CONCLUSION}

The research has investigated the students' reading habit on academic text. Finally, the research concludes that the students have sufficient reading habit on academic text, it is supported by several points as follows; (1) Most of the students shows positive feeling on academic text by admitting their enjoyment on reading the academic text (2) Most of the students frequently read academic text at least once in a week (3) Academic book is the most type of academic text read by the students (4) Busy with assignment becomes the most dominance factor for not reading academic text.

The conclusion of the research has prompted the plausible speculation that students have sufficient reading habit on academic text. A tentative suggestion might be; (1) In the process of teaching and learning at university context, students should be more familiar with the various kinds of academic text in the early year of semester, (2) lectures and stake holders should involve the academic text context for the students' assignments and learning material, (3) Other authors have also called for the future research to do inquiry on the other issues related to academic text.

Confirming University Students' Individual Reading Habit on Academic Text

Herman Resyadi, Dea Serly Safitri, \& Darmawati Fitriansyah, Page 1-6 
IJRETAL

International Journal of Research on English Teaching and Applied Linguistics, Vol. 1, No.1, June 2020

\section{REFERENCES}

Acheaw-Owusu, M. (2014). Reading Habits among Students and Its Effect nn Academic Performance: A Study of Students of Koforidua Polytechnic. University of Nebraska, Nebraska.

Annamalai, S., \& Muniandy, B. (2013). Reading Habit and Attitude among Malaysian Polytechnic Students. International Online Journal of Educational Science, 5(1), 3241.

Anyaegbu, M. I., Ekene, A. E., \& Eucharia, N. (2016). Poor Reading Habit and the Academic Performance of Junior Secondary School Students in Enugu South Local Government Area of Enugu State. University Awka, Nnamdi Azikiwe.

Aukerman, M., \& Schuldt, L. C. (2015). Children's Perception of Their Reading Ability and Epistemic Roles in Monologically and Dialogically Organized Bilingual Classrooms. Journal of Literacy Research.

Chettri, K., \& Rout, S. K. (2013). Reading Habits-An Overview. 14(6), 13-17.

Cimmiyotti, C. B. (2013). Impact of Reading Ability on Academic Perpformance at the Primary Level. Dominican University of California, California.

Erlina, D., astrid, A., Kurniasari, R., \& Purwansyah, H. (2019). The Correlation between Reading Habit and Academic Achievement of the Undergraduate Students of English Education Study Program of UIN Raden Fatah Palembang. Jambi-English Language Teaching Journal, 4(1), 48-57.

Iftanti, E. (2012). A Survey of the English Reading Habits of EFL Students In Indonesia. TEFLIN Journal, 23(2).

Kurniasih, N. (2017). Reading Habit in Digital Era: Indonesian People do not Like Reading, is it True? , Universitas Padjadjaran, Sumedang.

Maharsi, I., Ghali, M., \& Maulani, S. (2019). High School Students' Reading Habit and Perception on Reading for Pleasure. International Journal of Indonesian Education and Teaching, 3(1).

Palani, K. K. (2012). Promising Reading Habits and Creating Literate Social. International Reference Research Journal, 3(2), 91.

Rosli, N. A., Razali, N. F., Zamil, Z. U. A., Noor, S. N. F. M., \& Baharuddin, M. F. (2017). The Determination of Reading Habits among Students: A Concept. International Journal of Academic Research in Business and Social Sciences, 7(12).

Shen, L.-B. (2006). Computer Technology and College Students' Reading Habits. Chia-nan annual bulletin, 32, 559-572.

Skenderi, L., \& Ejupi, S. (2017). The Reading Habits of University Students in Macedonia. Republic of Macedonia: University of Tevoto.

Syahputra, P. A. (2016). Applied Linguistic Post Graduate Students' Reading Habit and Strategies in Acquiring Vocabulary the Outline. Retrieved 24 August, 2019' 